\title{
Corpo e subjetividade: espaços e experiências
}

\author{
Valéria A S Machado* \\ Vinícius Lourenço Linhares**
}

\begin{abstract}
Resumo
Este texto busca empreender aproximações entre a leitura dos contos "Paulo", de Graciliano Ramos e "A bela e a fera ou a ferida grande demais", de Clarice Lispector, tendo como perspectiva a relação entre corpo, espaço e subjetividade. No espaço ambivalente e paradoxal que é a própria escrita, pretende-se analisar o modo como o corpo se delineia no espaço da cidade ficcional, também ela permeada de paradoxos e ambivalências. No corpo do sujeito que experimenta a dinâmica das relações que a cidade impõe a seus habitantes, inscreve-se a incômoda presença do outro e do outro de si, o que pode ser entrevisto na imagem do duplo, levando a formas variadas de constituição subjetiva, ainda que pelo doloroso enfrentamento da morte e da exposição da ferida social e existencial.
\end{abstract}

Palavras-chave: Escrita. Espaço. Corpo. Duplo. Subjetividade.

\section{Body and subjectivity: spaces and experiences}

\begin{abstract}
The aim of this paper is to establish approximations in the reading of the short stories "Paulo", by Graciliano Ramos and "A Bela e a Fera ou a Ferida Grande Demais", by Clarice Lispector from a perspective that relates body, space and subjectivity. In the ambivalent and paradoxical space that is the writing itself, the intention of this text is to analyze the way the body is delineated in the space of the fictional city which is also permeated by paradoxes and ambivalences. In the subject's body that is experiencing the dynamics of the relations imposed by the city on its inhabitants, it is also inscribed the uncomfortable presence of the other and the other from oneself. This can be glimpsed in the image of the double, leading to diverse forms of subjective constitution even through the painful confrontation of death and the social and existential wound.
\end{abstract}

Keywords: Writing. Space. Body. Double. Subjectivity.

Recebido: $15 / 02 / 2018$

Aceito: $24 / 04 / 2018$

* Pontifícia Universidade Católica de Minas Gerais (PUC Minas) - Doutora em Literaturas de Língua Portuguesa.

** Pontifícia Universidade Católica de Minas Gerais (PUC Minas) - Doutorando Literaturas de Língua Portuguesa (Bolsista CAPES). 


\section{Introdução}

A perspectiva a que nos propomos neste trabalho é perceber a relação entre corpo, espaço e subjetividade que se delineia nos contos "Paulo", de Graciliano Ramos e "A bela e a fera ou a ferida grande demais", de Clarice Lispector. Antes, queremos salientar o espaço da escrita como espaço paradoxal e ambivalente no qual se configura uma heterogeneidade de pontos de vista que, ao serem postos em diálogo, vão nos mostrar as muitas vozes que essa escrita tensiona.

As relações que os sujeitos experimentam no espaço da cidade, por exemplo, também ele paradoxal e ambivalente, são relações que se inscrevem em seus corpos, revelando experiências várias que estão ali, para serem lidas e (re)significadas no corpo e no espaço da escrita. Essas experiências dão-se sempre na presença e na dependência do outro, levando a formas variadas de constituição subjetiva, ou melhor, intersubjetiva. São subjetividades que se constroem ainda que pelo doloroso enfrentamento da morte ou da exposição de uma ferida social / existencial, mas que levam a uma movimento de (re) conhecimento daquilo que nos foge e nos aflige: nossa incompletude, nossa falta, nosso ser dividido entre o instintual (o prazer, o desejo) e o social (a lei, as regras, a repressão).

A perspectiva que aqui consideramos em relação à constituição da subjetividade é aquela que a concebe na e pela linguagem, sempre na presença de um outro, como primeiramente postula a Teoria Psicanalítica, ao sustentar que o sujeito é de ordem intersubjetiva. Para se constituir, ele passa e é atravessado pelo outro como forma de inscrever suas pulsões no universo de representação, pela mediação do simbólico, ou seja, da linguagem. Esta, por sua vez, é primordial na constituição do sujeito porque o distingue dos outros, conferindo a ele sua singularidade. A essa fundamentação teórica podemos aproximar as teorias da enunciação postuladas por Bakhtin e Benveniste, aqui também consideradas e que, por sua vez, opõem-se à tese da linguagem vista de modo abstrato.

Em Bakhtin nos interessa a abordagem social da linguagem e sua concepção pelo viés dialógico, segundo a qual a linguagem deve ser compreendida em termos de sua orientação inevitável para outro indivíduo, considerando, ainda, que grupos sociais, classes, indivíduos e discursos conflitantes tentam se apropriar do signo e impregná-lo de seus próprios significados. (cf. Eagleton, 2006, p.175176). Já Benveniste nos mostra que "a consciência de si mesmo só é possível se experimentada por contraste" (BENVENISTE, 1995, p.286), o que permite compreender a intersubjetividade, anterior à subjetividade, como a "condição da presença do homem na linguagem na qual o eu e o outro se pressupõem mutuamente”. (FERREIRA JÚNIOR; FLORES; CAVALCANTE; 2015, p.531).

A tudo isso, relacionamos a figura do duplo que instaura e mostra a cisão do sujeito; imagem que se opõe ao eu, mas que também o constitui. A figura do duplo nos remete ao conceito de "estranho" (Freud. 1996), em um primeiro momento relacionado a tudo que é assustador. O estranho, de alguma forma, também se desenvolve na direção da ambivalência, até coincidir com seu oposto: é algo que se esconde e se oculta, mas que, ao mesmo tempo, tem alguma coisa que nos é familiar. Ainda que familiar, o estranho seria aquilo que se esconde da vista; que estaria inacessível ao conhecimento (o inconsciente?). Daí o jogo que Freud faz com a palavra 'heimlich' e o prefixo 'un', formando 'unheimlich': aquilo que uma vez foi 'heimlich' (familiar) e que é reprimido, tornando-se estranho, não familiar. O prefixo seria, segundo Freud, o sinal da repressão.

Desse modo, o duplo pode estar conectado a um período muito primitivo do estado mental (e por isso o tom de familiar) que causa estranhamento no sujeito quando algo dessa fase aparece / retorna, ou seja, refere-se a um esforço psíquico de resgate de algo antes reprimido. Por outro lado, o duplo também se liga a mecanismos de autocrítica e autoconhecimento, já que coloca a outra face que aponta para a divisão, a duplicação, o intercâmbio do eu.

Nos contos analisados, os personagens, nas relações que estabelecem no espaço da cidade (um no hospital, caso de Graciliano; outro na rua, caso de Clarice), experimentam / enfrentam o encontro 
com o outro que. direta ou enviesadamente. vão desembocar na figura do duplo, a escancarar a outra face do eu. Nosso objetivo, portanto, é perceber, nos dois contos, como o sujeito se constitui, tendo o corpo como elemento canalizador que vai levar ao (re)conhecimento e ao encontro do outro e do outro de si, assim como despertar a consciência da precariedade do estar do homem no mundo e suas injunções permeadas por distintas relações de poder.

\section{Corpo delirante}

O conto "Paulo", inserido no livro Insônia, de 1947, encena a história de um homem que se encontra num hospital, à beira da morte. Em meio a delírios e devaneios, o eu se desdobra levando o personagem a um processo de reflexão sobre si e sua vida. O outro, atribuído ao lado direito do corpo que se abre em ferida, força o personagem, ele também o narrador, a lidar com a fragilidade da vida diante da morte e a tensão entre as duas instâncias do eu: o "ser social" e o "ser profundo" (cf. Candido, 2006).

No espaço objetivo e reduzido do quarto de hospital, o personagem experimenta a realidade de um corpo doente e purulento, que indicia a presença iminente da morte. Esse espaço intercala-se com outro, o espaço subjetivo no qual o personagem mergulha entre delírio e devaneio, levando-o a experimentar, também, uma outra realidade - o real que lampeja entre uma cena e outra.

Enunciado na primeira pessoa, o conto opera um jogo de luz e sombra que entrecruza espaços e tempos nas idas e vindas de pensamentos e reminiscências, misturando o "aqui" com o "lá fora". A realidade objetiva do quarto de hospital é deformada por lapsos de lembranças que criam o estado de devaneio, marcado por elementos que borram a nitidez de fatos, objetos e pessoas: garoa, fisionomias apagadas, sombra pálida, neblina densa, escuridão.

Na construção da narrativa, o ambiente é preparado para o encontro do personagem com seu duplo. Nesse ponto, interessa notar que a percepção do despedaçamento (a primeira palavra da narrativa é "pedaços") se inicia no momento em que todas as vidraças são abertas. Aí temos não só a analogia ao espelho, mas a algo oculto que vem à luz (o estranho, o duplo). Nessa cena inicial, os tempos são embaralhados, deixando ver um tempo ligado à infância: imagens de crianças se misturam às imagens do hospital e mundos diferentes interagem, ainda que sua distinção seja dificultada, porque englobados no devaneio:

Pedaços de algodão e gaze amarelos de pus enchem o balde. Abriram todas as vidraças. E no calor da sala mergulho num banho de suor...

As crianças estiveram a correr no chão lavado a petróleo.

- Retirem essas crianças.

Inútil trazê-las aqui, mostrar-lhes o corpo que se desmancha numa cama estreita de hospital. Não as distingui bem na garoa que invade a sala: são criaturas estranhas, a recordação das suas fisionomias apagadas fatiga-me. (RAMOS, 2001, p. 48).

Corpo e espaço não se distinguem, fazendo coincidir a podridão do ambiente e a desagregação do sujeito: "As paredes amarelas cobrem-se de pus, o teto cobre-se de pus. A minha carne, que apodrece, suja a gaze e o algodão, espalha-se no teto e nas paredes". (RAMOS, 2001, p. 48) ${ }^{3}$. O fluxo de consciência, que funde o "aqui" e o "lá fora", evoca imagens difusas, que levam ao desdobramento do personagem. É significativa, nesse sentido, a imagem feminina, assim descrita pelo narrador: "uma figura de mulher... uma vida que esteve presa à minha... Mas (...) pesa demais dentro de mim..." (RAMOS, 2001, p. 49). Essa cena parece se referir a um tempo tal da infância, aquele marcado pela dolorosa renúncia ao desejo da mãe. A sujeira das paredes e os pensamentos desordenados contrastam

3 A partir daqui, em citações curtas, de até três linhas, será indicado apenas o número da página entre parênteses. 
com "essa criatura, dificilmente organizada", como diz o narrador, apontando para a renúncia / repressão do desejo. Não por acaso a "mulher que esmorece, transforma-se em sombra pálida". (RAMOS, 2001, p. 49).

O jogo narrativo também oscila entre vida e morte, desejo e recusa do desejo, imaginação e realidade. Toda a atividade fantasiosa do personagem parece se ligar a uma realidade insatisfatória vivida no presente e que motiva a busca da satisfação em outros tempos e espaços que se contrapõem ao tempo e espaço presente (a esse respeito, ver a menção que Freud faz ao movimento da fantasia e do devaneio). Atentemos às imagens suscitadas pelo conto: as crianças barulhentas, que remetem à infância; a figura da mulher, ligada ao desejo erótico infantil; o desejo de se libertar das ataduras que envolviam o corpo na cama do hospital:

[...] Enquanto amarravam a atadura, os enfermeiros me levantavam, e eu me sentia leve, parecia-me que ia voar, flutuar como balão, esgueirar-me por uma janela, fugir do cheiro de petróleo e do calor, ganhar o espaço, fazer companhia aos urubus. As palmas dos coqueiros ficariam longe, na praia branca, invisíveis como a mulher que desapareceu na sala neblinosa. Os meus olhos não podem varar esta neblina densa. (RAMOS, 2001, p. 49).

Todas as experiências vividas pelo personagem, aquelas da realidade objetiva e as evocadas pelo devaneio, estabelecem-se numa relação sinestésica em que o corpo (físico e psíquico) é convertido em espaço que comporta / suporta dor e satisfação.

O desejo de liberdade do corpo que quer "flutuar como balão" esbarra na imobilidade do personagem preso à cama. Tal contraste reforça a duplicação desse sujeito, dividido entre a liberdade do desejo e o aprisionamento das imposições sociais, metáfora das "horríveis paredes". Nesse desdobramento de eus, como assinala Antonio Candido (2006),

[...] passam a colidir no mesmo indivíduo um ser social, ligado às necessidades de ajustarse a certas normas convencionais para sobreviver, e um ser profundo, revoltado contra elas, inadaptado, vendo a marca da contingência e da fragilidade em tudo e em si mesmo... (CANDIDO, 2006, p. 114).

O jogo de luz e sombra operado pela narrativa é também um jogo especular onde oscilam as presenças do eu e do outro; os dois lados do corpo dividido. Da ideia de podridão e sujeira incrustadas no corpo ferido - podridão e sujeira que também se espalham pelas paredes do quarto -, surge a presença incômoda do outro que o personagem não quer ver. Mas as pálpebras cerradas, o olhar desviado, não impedem que os "olhos de mal-assombrado" do outro sejam espelhos a refletir o próprio eu e a ferida social e existencial a que ele está exposto: "A ferida tortura-me, uma ferida que muda de lugar..." (p. 50). Esse sujeito abandonado, atormentado pelo eu que se desdobra e parece estranho, é acolhido pela escrita, também ela causadora de estranhamento na medida em que rompe com a ordem e a simetria ao embaralhar tempos, misturar espaços, deixar que se confundam estados oníricos e devaneios, a pedaços de uma realidade objetiva.

A ideia de despedaçamento do corpo em decomposição aponta para o homem dilacerado que arduamente se reconhece cindido. Esse ser mutilado reconhece sua impotência diante das duas faces: uma medonha, pouco conhecida, mas intimamente ligada à liberdade e ao desejo; outra organizada, culturalmente adestrada, relacionada às rotinas, às regras e obrigações sociais:

Fecho os olhos, vexado, como um menino surpreendido a praticar tolice. Finjo dormir... Contenho a respiração, o suor corre-me na cara e no pescoço.

Lá fora eu era um sujeito aperreado por trabalhos maçadores, andava para cima e para baixo, como uma barata. Nunca estava em casa. Recolhia-me cedo, mas o pensamento corria longe, fazia voltas em redor de negócios desagradáveis. Recordações de tipos 
odiosos, rancor, a idéia de ter sido humilhado, muitos anos antes, por um sujeito que se multiplicava. (RAMOS, 2001, p. 53).

Notemos que a construção com o verbo no pretérito imperfeito - "eu era" - indica a forte presença desse "intruso" que, segundo o personagem, em sua agonia delirante, quer apoderar-se dele, mas contra o qual ele luta para fazer calar. Ainda sobre o tempo do verbo, é interessante pensar que seu uso também indicie a indeterminação desse intruso, pouco ou nada palpável que, por analogia, pode ser associado ao imaginário: imperfeito, informe, inacabado, nunca superado pelo sujeito, apesar de atravessado por ele:

Evidentemente uma pessoa achacada tomou conta de mim. Esta criatura surgiu há dois meses, todos os dias me xinga e ameaça, especialmente de noite ou quando estou só... O homem que se apoderou do meu lado direito não tem cara e ordinariamente é silencioso. Mas incomoda-me. Defendo-me, grito palavrões, e o sem-vergonha escuta-me com um sorriso falso, um sorriso impossível, porque ele não tem boca. (RAMOS, 2001, p. 53-54).

O incômodo causado pelo outro ameaça e desequilibra o ser social e organizado e, por isso mesmo, não merece o reconhecimento, precisa ser eliminado. Notemos, no entanto, a ambiguidade com que o conto se constrói quando nos apresenta um personagem-narrador sem nome, mas que nomeia o seu duplo, chamando-lhe Paulo (de estranho, ele não passa a familiar?). Ora, o ato de nomear significa (re)conhecimento. Nomear é tornar visível, dar a conhecer. Quando o outro ganha um nome, o personagem entra num processo angustiante de decifração desse outro e de si mesmo. $\mathrm{O}$ duplo se relaciona, justamente, à identidade do ser. Nesse sentido, podemos pensar que a tentativa de decifrar esse "intruso" revela um exercício de alteridade que põe, também em jogo, as partes de que o sujeito se constitui.

Prestemos atenção na presença insistente da palavra que deseja compreender / representar aquilo que, por natureza, não se deixa apreender: "Tentei ler um jornal. As linhas misturavam-se, indecifráveis. Receei endoidecer, mastiguei uns nomes que minha mulher não entendeu...” (p. 54, grifos acrescentados). Nesse ponto, vale repetir: o sujeito se constitui na e pela linguagem. Não é por acaso, pois, que o personagem, ao nomear Paulo, inicia um "discurso"; "uma espécie de conferência para explicar quem é Paulo...” (p. 54). Tentativa de simbolizar o outro pela linguagem. Mas a tentativa é malograda porque "realmente Paulo é inexplicável: falta-lhe o rosto e o seu corpo é esta carne que se imobiliza e apodrece, colada à cama do hospital”. (p. 54).

Aqui temos um duplo reconhecimento: um primeiro, de que esse lado podre é também parte que constitui o personagem; ao dizer "esta carne" e "colada", ele aponta para o próprio corpo; um segundo, de que o outro está fora do que pode ser capturado pela linguagem porque amorfo, esquivo à fala, não pode ser visto; é só escuridão e sombra.

$\mathrm{Na}$ impossibilidade de explicar / simbolizar Paulo, a doença, o pus, a dor, a podridão do corpo, tudo é, então, associado a ele como causa do desconforto. Isso indicia o abalo narcísico, o eu que entra em colapso ao reconhecer o outro de si (ou a 'ferida grande demais', nos termos de Clarice). O abalo sentido pelo corpo ressoa nos delírios do personagem a embaralhar tempos, espaços e pessoas:

A escuridão se atenua, o burburinho confuso reaparece, a camisa torna a queimar-me a pele, os dentes calam-se. Incomoda-me a pressão que me fazem no pulso, tento libertar o braço. A mão desconhecida tateia, procurando a artéria. Há um zunzum na sala, vozes confundemse como rumor de asas num cortiço. Sinto ferroadas terríveis na ferida.

Os dedos seguram-me, tenho a impressão de que Paulo me agarra... (RAMOS, 2001, p. 55).

O outro, Paulo, faz contraste com os valores arraigados, as amarras sociais, as regras que moldaram e marcaram as relações do personagem com os outros: “[...] berros de patrões, ordens, exigências, 
choradeira, gemidos, pragas, transformam-se num sussurro de abelhas que Paulo me sopra ao ouvido..." (p. 55). Mas Paulo é ignorado, negado pelo outro que se agarra a "pedaços de realidade: visitas de amigos, colheres de remédio, a comida horrível..." (p. 55). Paulo representa uma ameaça ao lugar organizado e ocupado pelo personagem há muito tempo e do qual ele custa a abrir mão para (re)conhecer o outro. A "cura" de que ele fala inclui a eliminação desse lado que estampa a ferida quando expõe o eu como ser faltante. Livrar-se dessa imagem traria alívio e talvez a vida voltasse à sua corriqueira normalidade. Mas Paulo é a própria ferida que desorganiza a vida organizada do personagem. O corpo, então, acede a esse outro que mostra, como comenta Ivete Walty (2017), a "violência incorporada, a violência contra si mesmo" (WALTY, 2017, p.15). A ferida está ali, atravessa e violenta o corpo:

A ferida começa a torturar-me... Veio-me um acesso de tosse, e o tubo de borracha que me atravessa a barriga parece um punhal. Gemo, o suor corre-me entre as costelas magras como as de um cachorro esfomeado... Os soluços sacodem-me, rasgam-me, enterram-me o punhal nas entranhas. (RAMOS, 2001, p. 56).

No jogo de recusa e aceitação, vemos um movimento que acolhe, reconhece o outro, ainda que ele cause repugnância e estranhamento. Esse é, aliás, o movimento da narrativa e da própria escrita de Graciliano, que não nega o outro, mas também não esconde a dificuldade dessa convivência. Nesse aspecto, como bem assinala Walty (2017), "a ideia de desdobramento leva ao ato de dobrar-se sobre si mesmo, sobre o outro, sobre a sociedade e sobre o ato da escrita" (WALTY, 2017, p. 15). Isso não quer dizer que há resolução ou apaziguamento, mas abre a possibilidade de reconhecimento das diferenças que se friccionam no espaço social, no espaço psíquico, no espaço da escrita para mostrar a incompletude do homem que ri de si mesmo ao saber-se irremediavelmente dilacerado:

Paulo está curvado por cima de mim, remexe com um punhal a ferida. Estertor de moribundo na floresta, perto de um pântano...

Não conheço Paulo. Tento explicar-lhe que não o conheço, que ele não tem motivo para matar-me. Nunca lhe fiz mal, passei a vida ocupado em trabalhos difíceis, caindo, levantando-me, cansado...

Mentira. Sempre vivemos juntos... Desejo que me operem e me livrem dele.

Paulo compreende-me. Curva-se, olha-me sem olhos, espalha em roda um sorriso repugnante e viscoso que treme no ar. (RAMOS, 2001, p. 56-57).

\section{Corpo mutilado}

O conto "A Bela e a Fera ou A Ferida Grande Demais", de Clarice Lispector, inserido no livro A Bela e a Fera, de 1979, à semelhança do conto de Graciliano, também encena a experiência vivida pelos personagens a partir de um encontro que ocorre no espaço da rua. Experiência que, indubitavelmente, passa pelo corpo das personagens.

Sem deixarmos de considerar a fortuna crítica da obra de Clarice, vasta e variada, mas impossibilitados de dialogar com outros estudos sobre o mesmo conto em razão dos limites deste texto, interessa-nos conduzir a leitura do conto de Clarice a partir da seguinte problemática: como o encontro entre as personagens do / no conto encena a experiência da protagonista de reconhecimento de si diante do outro, o mendigo? E mais: como essa experiência, no conto, passa pelo corpo?

A ação do conto se passa numa tarde de maio, quando a personagem Carla, ao sair do salão de beleza, às $16 \mathrm{~h}$, permanece na calçada até a chegada de seu motorista, seu José, com o qual marcou 
para vir buscá-la, às $17 \mathrm{~h}$. É nesse intervalo de tempo que se dá o encontro de Carla com "um homem sem uma perna - agarrando-se numa muleta", que "parou diante dela" (LISPECTOR, 2017, p.54) ${ }^{4}$ pedindo-lhe dinheiro para comer.

A partir de então, se inicia o doloroso processo enfrentado por Carla de reconhecimento de si diante do mendigo, culminando no fato de ela mesma se reconhecer como "mendiga", pois o mendigo, ao expor sua "grande ferida" na perna e o corpo mutilado expresso na ausência da outra perna, amputada, acaba por denunciar Carla a si própria quanto a sua condição de desconhecimento de si mesma, individual e socialmente. O mendigo é, assim, o duplo da personagem, revelando à Carla (e a cada um de nós) a verdade fulminante: a "criminosa" que persigo, sou eu mesma, pois a ferida do mendigo é a minha ferida. Esse encontro desencadeia o movimento de (re)conhecimento do mendigo e de Carla.

Esse processo, necessariamente intersubjetivo, é conduzido por um narrador cuja voz, por vezes, imiscui-se na de Carla, revelando ao leitor as intuições, desconfianças da personagem de que as imagens que até então ela fazia de si talvez estivessem mascarando algo (sua "grande ferida") prestes a irromper, ganhar forma e se encarnar no corpo do mendigo, quando do confronto / encontro com ele. O narrador, colado a Carla, põe em cena as angústias da personagem que, de pé na rua, após sair "do salão de beleza pelo elevador do Copacabana Palace Hotel” (p.54),

Não se lembrava quando fora a última vez que estava sozinha consigo mesma. Talvez nunca. Sempre era ela - com outros, e nesses outros ela se refletia e os outros refletiamse nela. Nada era - era puro, pensou sem se entender. Quando se viu no espelho - a pele trigueira pelos banhos de sol fazia ressaltar as flores douradas perto do rosto nos cabelos negros -, conteve-se para não exclamar um “ah!” - [...]. (LISPECTOR, 2017, p.54, grifos acrescentados).

Mirando-se no espelho, a imagem que Carla vê é a imagem de seus pares. É uma imagem, pois, opaca, visto que não há tensão, nem distorção, o que fica evidente em: "Sempre era ela - com outros, e nesses outros ela se refletia e os outros refletiam-se nela." Esses outros, os pares de Carla, são as "manadas de mulheres e homens que, sim, que simplesmente 'podiam'." (p.54, grifos acrescentados).

Ainda que aí se estabeleçam as trocas intersubjetivas, estas ocorrem em um mesmo "campo de visão". Um "campo de visão" que mascara o entorno social em que se encontra Carla, alienando-a e, também, mascara a condição humana da falta que é tamponada por signos sociais de prestígio. Esses signos são "adornos" sociais que acabam por inviabilizar que Carla se perceba como sujeito dotado de carências, sensibilidades e desejo, além, claro, da sua profunda alienação social, o que é mordazmente denunciado pelo narrador. O encontro com o mendigo que a interpela em novas possibilidades intersubjetivas permitirá que Carla perceba novas imagens de si e do outro. E agora não mais serão imagens de seus pares que reafirmam a imagem de si que Carla faz, mas outra imagem que vai pôr em questão as imagens que até então eram percebidas por ela - tanto no plano individual, quanto no social.

Para que isso ocorra, a voz do narrador cumpre importante papel no sentido de ir tensionando essas imagens. Observemos, no trecho que segue, a construção da imagem a partir da qual Carla (e seus pares) se enxergava(m) e como o narrador vai ironizando tal imagem:

Ela tinha um nome a preservar: era Carla de Sousa e Santos. Eram importantes o "de" e o "e": marcavam classe e quatrocentos anos de carioca. Vivia nas manadas de mulheres e homens que, sim, que simplesmente "podiam". Podiam o quê? Ora, simplesmente podiam. E ainda por cima, viscosos pois que o "podia" deles era bem oleado nas máquinas que corriam sem barulho de metal ferrugento. Ela, que era uma potência. Uma geração de energia elétrica. Ela, que para descansar usava os vinhedos do seu sítio. Possuía tradições

4 A partir daqui, em citações curtas, de até três linhas, será indicado apenas o número da página entre parênteses. 
podres mas de pé. E como não havia nenhum novo critério para sustentar as vagas e grandes esperanças, a pesada tradição ainda vigorava. Tradição de quê? De nada, se se quisesse apurar. Tinha a seu favor apenas o fato de que os habitantes tinham uma longa linhagem atrás de si, o que, apesar de linhagem plebeia, bastava para lhes dar uma certa pose de dignidade.

Pensou assim, toda enovelada: "Ela que, sendo mulher, o que lhe parecia engraçado ser ou não ser, sabia que se fosse homem, naturalmente seria banqueiro, coisa normal que acontece entre os 'dela', isto é, de sua classe social, à qual o marido, porém, alcançara com muito trabalho e que o classificava de "self made man" enquanto ela não era uma "self made woman". No fim do longo pensamento, pareceu-lhe que - que não pensara em nada. (LISPECTOR, 2017, p. 54, grifos acrescentados).

O narrador, aí, reporta a fala de Carla em vários momentos, criticando abertamente o discurso meritocrático, a tradição e expondo as relações de poder que sustentam todo o universo social do qual Carla, o marido e seus pares fazem parte e as incoerências desse universo prestes a ruir aos olhos da personagem. Viver nas "manadas" reafirma a alienação tanto de Carla, quanto de seus pares, cuja forma de existência se reduz à posse de bens materiais, exibição de nomes e sobrenomes, linhagem e tradição como forma de marcarem distinção em relação aos demais.

Consideremos, ainda, que a adoção de hábitos iguais contribuía para manter o grupo homogêneo e coeso, assim como agem os animais em manada para se manterem unidos e fortalecidos. É uma existência sem reflexão coroada pelo universo das aparências, encobrindo uma linhagem plebeia, cujas "tradições são podres, mas de pé". Tal imagem, além de denunciar a falência do universo social do qual Carla faz parte, é reiterada, numa crítica ácida, na imagem do mendigo: também em pé, sem uma perna, agarrando-se numa muleta e na outra perna uma enorme ferida em carne viva e purulenta. Além da ironia ao jogo de aparências, o narrador ainda reforça seu escárnio ao discurso meritocrático, quando se vale dos signos em língua inglesa self made man e self made woman: expressões máximas do universo empresarial que encarnam e traduzem a ideia de meritocracia; aquela que atribui ao sujeito a responsabilidade de todas as suas conquistas e fracassos, barrando seu encontro com o outro, negando, assim, suas vivências sociais. Não bastasse o discurso meritocrático, empresarial, há, ainda, o agravante de que a condição de self made valha apenas para o homem, relegando a mulher à condição de troféu arrematado em leilões da alta sociedade como foi o caso de Carla. O narrador finaliza sua crítica corrosiva a esse universo social ironizando o "longo pensamento" da personagem, criticando sua cegueira, ao não se aperceber das incoerências no modo como vive, além de expor sua incapacidade para refletir criticamente diante da realidade da qual faz parte. Na ironia do narrador, o "longo pensamento" de Carla é, na verdade, a ausência de pensamento.

A partir daí ocorre o encontro com o mendigo, o que se constitui como uma espécie de ponto detonador na narrativa a partir do qual Carla vivencia uma experiência de (re)conhecimento de si ao "atravessar" e ser "atravessada" pelo mendigo, cuja "grande ferida" em uma perna e a ausência da outra, amputada, são igualmente a grande ferida e a mutilação (para além do corpo físico) de Carla. Leiamos a cena:

Um homem sem uma perna, agarrando-se numa muleta, parou diante dela e disse:

- Moça, me dá um dinheiro para eu comer?

"Socorro!!!" gritou-se para si mesma ao ver a enorme ferida na perna do homem. (LISPECTOR, 2017, ps.54-55).

Carla e o mendigo são duas faces opostas de uma mesma moeda: ela tem marido dono de banco, tem apartamento, tem casa de campo, tem joias, tem um motorista; ao passo que o mendigo tem o excesso de faltas: falta-lhe casa, falta-lhe comida, faltam-lhe os dentes ("gengivas quase vazias"), falta-lhe uma perna e, na perna que restou, há uma enorme ferida. $\mathrm{O}$ excesso de falta no mendigo 
pareia com o excesso de bens materiais de Carla que, no entanto, padece da mesma falta do mendigo, aliás, a mesma falta de que todos nós padecemos. Observemos, por exemplo, como ocorre esse pareamento por oposição no corpo da narrativa:

Enquanto isso a cabeça dele pensava: comida, comida, comida boa, dinheiro, dinheiro. A cabeça dela era cheia de festas, festas, festas._Festejando o quê? Festejando a ferida alheia?

Uma coisa os unia: ambos tinham uma vocação por dinheiro. [...] Se fosse moço, poderia ser pintor de paredes. Como não era, investia na ferida grande em carne viva e purulenta. Não, a vida não era bonita. (LISPECTOR, 2017, p. 55, grifos acrescentados).

Vejamos nos grifos iniciais, a oposição entre Carla e o mendigo e, em seguida, o dinheiro que os une. O contato com o mendigo fez Carla "olhar para dentro de si” (p.56) e, então, inicia-se o momento em que ela parece sair de um transe: "De repente - de repente tudo parou. Os onibus pararam, os carros pararam, os relógios pararam, as pessoas na rua imobilizaram-se - só seu coração batia, e para quê?” (p.56). Nesse momento, é como se Carla divisasse outra imagem de si, até então ignorada, ao ser confrontada pelo mendigo. Dá-se, aí, o reconhecimento, por parte de Carla, da sua própria ferida. A "ferida grande em carne viva e purulenta" (p.56), em cuja construção há a associação de duas imagens em contraste: vida e morte tensionadas na ferida do mendigo que, nesse instante do conto, já não é mais apenas do mendigo. Intersubjetivamente, Carla é atravessada pela ferida do mendigo, reconhecendo a si mesma como também dona daquela ferida grande. É o exato momento em que ela vê o outro de si ao olhar para o mendigo. Além disso, "em carne viva e purulenta" vê-se uma ferida existencial, além do que, a imagem sugere tanto o apodrecimento do corpo do mendigo, quanto o apodrecimento do corpo social com suas profundas desigualdades materiais. Desigualdades que se fazem sentir na carne do mendigo, mas que também mutilam outros sujeitos que, embora em condições materiais mais abastadas (o caso de Carla), ao serem privados de sua condição subjetiva, tornam-se, também, mutilados. Daí o ponto em que Carla e o mendigo, ainda que em condições materiais distintas, se irmanam: em ambos, a negação às suas subjetividades passa pelo corpo. No mendigo se concretiza na perna amputada, na ferida grande, e nas "gengivas quase vazias" e no fato de ele não ser nomeado; já em Carla, seu corpo também é mutilado, como podemos ler no excerto que se segue:

[...] 'Antes de casar era de classe média, secretária de banqueiro com quem se casara agora e agora - agora luz de velas. Estou é brincando de viver, pensou, a vida não é isso'. 'A beleza pode ser de uma grande ameaça.' 'A beleza assusta.' . 'Se eu não fosse tão bonita teria outro destino'. (...) Como se assustara com o homem da ferida ou com a ferida do homem. Teve vontade de gritar para o mundo: "Eu não sou ruim! Sou um produto nem sei de quê, como saber dessa miséria de alma". Para mudar de sentimento - pois que ela não os aguentava e já tinha vontade de, por desespero, dar um pontapé violento na ferida do mendigo - para mudar de sentimentos pensou: este é o meu segundo casamento, isto é, o marido anterior estava vivo. Agora entendia por que se casara da primeira vez e estava em leilão: quem dá mais? Quem dá mais? Então está vendida. Sim, casara-se pela primeira vez com o homem que "dava mais", ela o aceitara porque ele era rico e era um pouco acima dela em nível social. Vendera-se. E o segundo marido? Seu casamento estava findando, ele com duas amantes... e ela tudo suportando porque um rompimento seria escandaloso: seu nome era por demais citado nas colunas sociais. E voltaria ela a seu nome de solteira? Até habituar-se ao seu nome de solteira, ia demorar muito. Aliás, pensou rindo de si mesma, aliás, ela aceitava este segundo porque ele lhe dava grande prestígio. Vendera-se às colunas sociais? Sim. Descobria isso agora. Se houvesse para ela um terceiro casamento - pois era bonita e rica - , se houvesse, com quem se casaria? Começou a rir um pouco histericamente porque pensara: o terceiro marido era o mendigo. (LISPECTOR, 2017, p. 57, grifos acrescentados). 
Na passagem, observemos o uso, que aparece quase na totalidade do conto, do chamado discurso indireto livre: técnica por meio da qual o narrador assume a palavra, mas sua voz encontra-se tão próxima à voz da personagem, que o discurso de ambos se confunde. No conto, essa técnica funciona exatamente como uma imagem especular, o duplo: o narrador funciona como uma espécie de tradutor de Carla, quando esta olha para o mendigo. O mendigo é o espelho para o qual Carla olha e, simultaneamente, vê o mendigo e vê a si mesma. O narrador vai traduzindo o olhar de Carla quando ela olha para o mendigo. Esse olhar tem uma dupla movimentação que ocorre de modo tensionado: primeiro ocorre o desconhecimento de Carla ao ver o mendigo: ela grita e lhe pergunta quanto "se costuma dar" (p.54). Evidencia-se, aí, a sua cegueira / seu desconhecimento (existencial e a social). O segundo movimento ocorre quando Carla se vê no mendigo e enuncia, em discurso direto, que: "Como é que eu nunca descobri que sou também uma mendiga?" (p.58). Esse segundo movimento é o do reconhecimento. É quando Carla se dá conta de que é tão desgraçadamente miserável quanto o mendigo. Semelhantemente ao mendigo que expõe sua ferida na perna como forma de sobrevivência, já que ele "investia na ferida grande em carne viva e purulenta" (p.55) e, com isso, realizava também o jogo perverso da sociedade capitalista ao se transformar em mercadoria a ser exposta e vendida, o que realça / intensifica a própria ferida existencial e social pela banalização da pobreza e da doença, Carla também mendiga e por isso diz: "Nunca pedi esmola mas mendigo o amor de meu marido, que tem duas amantes, mendigo pelo amor de Deus que me achem bonita, alegre, aceitável..." (p.58).

Além disso, o corpo de Carla também é espoliado, posto que fora vendido, violado, afinal, em suas reflexões ela mesma percebe que, se não fosse bonita, teria tido outro destino e que fora arrematada em um leilão ao casar com o primeiro marido. Da mesma forma ocorre no segundo casamento, em que Carla se vendeu ao nome e prestígio do marido, possuidor não só dela, mas de outras duas amantes. Quando, enfim, a personagem conclui que o terceiro marido seria o próprio mendigo, se expressa nessa conclusão uma elucidação quanto a sua condição de miséria humana. Miséria de afetos, miséria de sensibilidades, miséria de subjetividade. Se o corpo do mendigo está exposto, mutilado, ferido em "carne viva e purulenta", o corpo de Carla também está exposto, à venda, e é exatamente aí que ambos, pelo próprio corpo se irmanam, no corpo da narrativa.

O conto se encerra mantendo a tensão que o permeia do início ao fim, sem oferecer ao leitor um happy ending. Essa tensão que permanece é encarnada na narrativa como resistência a uma ordem social desumanizadora. Ela resiste a essa ordem porque Carla e o mendigo, na fabulação da narrativa, têm a possibilidade de se constituírem como sujeitos e os elementos da realidade social; selecionados e rearranjados no conto, constroem um outro olhar, outra visada para as relações sociais de que fazem parte. A ferida tratada no conto, inicialmente apenas inscrita no mendigo, se estende à Carla e, por fim, amplia-se e se inscreve / escreve em nós leitores; transforma-se em uma ferida que é de todos nós, apesar de, muitas vezes, estarmos impossibilitados de enxergá-la em função de uma ordem social que nos destitui de nossas experiências afetivas e subjetivas negando-nos, inclusive, o que mais fixa nossa identidade: nosso nome. Não sem razão o conto se finaliza com o pensamento de Carla ao se dar conta: "nem lembrei de perguntar o nome dele." (p.59).

\section{Conclusão}

As relações que os sujeitos experimentam no espaço da cidade - também ele paradoxal e ambivalente - são relações que se inscrevem em seus corpos, revelando experiências várias que estão ali, para serem lidas e (re)significadas no corpo e no espaço da escrita. Essas experiências se dão sempre na presença e na dependência do outro, levando a formas variadas de constituição subjetiva, ou melhor, intersubjetiva. São subjetividades que se constroem ainda que pelo doloroso enfrentamento da morte 
ou da exposição de uma ferida social e existencial, mas que levam ao (re)conhecimento daquilo que nos foge e nos aflige: nossa incompletude, nossa falta, nosso ser dividido entre o instintual (o prazer, o desejo) e o social (a lei, as regras, a repressão).

Em "A Bela e a Fera ou a Ferida Grande Demais", o outro se representa na figura do mendigo que força o olhar da mulher ao lhe expor a ferida social e a ferida narcísica, quando ela vê, nesse outro, o outro de si mesma. No conto de Graciliano, o outro é uma imagem criada pelo personagem e que se torna independente e ganha corpo, até mesmo nome. Ambos evocam a imagem do duplo, "uma cisão tornada independente e visível do eu", como postula Otto Rank (2013, p. 20). Nesse embate, sem dúvida doloroso, percebemos os personagens se constituindo em interlocução com esse outro, na estranheza do corpo desse outro que ‘toma corpo' até se tornar familiar. É pela linguagem, falando com o outro, que os personagens dos dois contos tomam consciência de sua precariedade humana, enxergando-se como sujeitos não inteiros, mas cindidos e faltantes. 


\section{Referências}

BAKHTIN, Mikhail. Língua, Fala e Enunciação. In: BAKHTIN, Mikhail. Marxismo e filosofia da linguagem. Tradução de Michel Lahud e Yara F. Vieira. 13.ed. São Paulo: Hucitec, 2009. p.93-113.

BAKHTIN, Mikhail. A interação verbal. In: BAKHTIN, Mikhail. Marxismo e filosofia da linguagem. Tradução de Michel Lahud e Yara F. Vieira. 13. ed. São Paulo: Hucitec, 2009. p.114-132.

BENVENISTE, Émile. O aparelho formal da enunciação. In: BENVENISTE, Émile. Problemas de Linguística Geral II. Tradução de Eduardo Guimarães et al. 2. ed. Campinas, São Paulo: Pontes, 1989 (vol. II). p. 81-90.

BENVENISTE, Émile. A linguagem e a experiência humana. In: BENVENISTE, Émile. Problemas de Linguística Geral II. Tradução de Eduardo Guimarães et al. 2. ed. Campinas, São Paulo: Pontes, 1989 (vol. II). p. 68-80.

CANDIDO, Antonio. Os bichos do subterrâneo. In: Ficção e confissão: ensaios sobre Graciliano Ramos. 3 ed. Rio de Janeiro: Ouro sobre Azul, 2006, p. 101-128.

EAGLETON, Terry. Teoria da literatura: uma introdução. Tradução de Waltensir Dutra - 6 ed. São Paulo: Martins Fontes, 2006.

FERREIRA JÚNIOR, José Temístocles; FLORES, Valdir do Nascimento; CAVALCANTE, Marianne Carvalho Bezerra. A Teoria de Benveniste sobre a pessoalidade e seus desdobramentos na enunciação infantil. DELTA. Documentação de Estudos em Linguística Teórica e Aplicada, v. 31, p. 527-558, 2015.

FREUD, Sigmund. Escritores criativos e devaneio. In: FREUD, Sigmund. Gradiva de Jensen e outros escritos. Tradução de Jayme Salmo. Rio de Janeiro: Imago, 1976, p. 144-158. (ESB, IX).

FREUD, Sigmund. O estranho. Tradução de Jayme Salomão. In: FREUD, Sigmund. Edição Standard brasileira das obras psicológicas completas de Sigmund Freud. v.17: história de uma neurose infantil e outros trabalhos. Rio de Janeiro: Imago, 1996. p. 275-315.

GEBRA, Fernando de Moraes; BARROS, Tânia Sturzbecher de. Subterrâneos da mente: o duplo em "Paulo", de Graciliano Ramos. Revista Eletrônica Voos. Vol. 2 (Dez/2009). Caderno de Letras. Estudos Literários, p. 74-85. Disponível em www.revistavoos.com.br/seer/index.php/voos/article/ download/52/53. Acesso em: 12 set. 2017.

ISER, Wolfgang. Os atos de fingir ou o que é fictício no texto ficcional. In: COSTA LIMA, Luiz. Teoria da literatura em suas fontes. Tradução de Heidrun Krieger Olinto e Luiz Costa Lima. 2 ed. Rio de Janeiro: Francisco Alves, 2002. v. 2, p. 955-987.

LISPECTOR, Clarice. A Bela e a Fera ou A Ferida Grande Demais. In: LISPECTOR, Clarice. A Bela e a Fera. 2017. Arquivo em PDF. < http://lelivros.live/book/baixar-livro-a-bela-e-a-fera-claricelispector-em-pdf-epub-e-mobi/ > Acesso em: 14 fev. 2017, p. 54-60.

RAMOS, Graciliano. Insônia. 27 ed. Rio de Janeiro/São Paulo: Record, 2001.

RANK, O. O duplo: um estudo psicanalítico. Tradução de E. L. Schultz. Porto Alegre: Dublinense. 2013.

WALTY, Ivete. Escritas das asperezas - uma leitura de Memórias do cárcere, de Graciliano Ramos. Revista Veredas. Associação dos Lusitanistas. 2017, p. 12-23. 